\title{
Characterization of grape cultivars for processing and fresh market production in a subtropical area
}

\author{
Sergio Ruffo Roberto ${ }^{1, *}$, Ronan Carlos Colombo ${ }^{1}$, Fábio Yamashita ${ }^{2}$, Alessandro Jefferson Sato ${ }^{3}$, Bruno da Silva
} Jubileu $^{4}$ and João Pedro Silvestre ${ }^{1}$

${ }^{1}$ Universidade Estadual de Londrina, Departamento de Agronomia, Londrina, PR, Brazil. ${ }^{2}$ Universidade Estadual de Londrina, Departamento de Ciência e Tecnologia de Alimentos, Londrina, PR, Brazil. ${ }^{3}$ Universidade Federal do Paraná - Campus de Palotina, Departamento de Agronomia, Palotina, PR, Brazil. ${ }^{4}$ Associação Brasileira de Agricultura Biodinâmica, Botucatu, SP, Brazil. *Corresponding author, E-mail: sroberto@uel.br

\section{ABSTRACT}

The aim of this research was to diversify the grape production system, currently based on table grapes, in the subtropical region of Parana state, Brazil, through the introduction of cultivars for processing and fresh market production. A field trial was carried out in an experimental vineyard of 'Isabel' and 'Jacquez' American grapes, as well as 'Cabernet Sauvignon' and 'Tannat' European grapes, located in the city of Maringá . Two cycles were evaluated (2003/2004 and 2004/2005 seasons). The phenological development of grape cultivars and the thermal demand (degree day - DD) were characterized in order to determine means to predict harvest. The physicochemical characteristics of berries and clusters were determined from early ripening to harvest. In the 2003/2004 season , the cycle duration of 'Isabel', 'Jacquez', 'Cabernet Sauvignon' and 'Tannat', as well their thermal demand were: $127,126,126$ and 139 days, and 1,238,1,287,1,221 and 1,382 DD, respectively. In the 2004/2005 season, the means were: $135,149,132$ and 139 days, and 1,308,1,454,1,295 and 1,375 DD, respectively. The production per plant and yield in 2003/2004 were: 3.0, 14.2, 3.2 and $12.9 \mathrm{~kg}$ per plant and 7.5, 35.5, 5.3 and $21.4 \mathrm{t} \mathrm{ha}^{-1}$, respectively, whereas in 2004/2005 the means were: 9.9, 15.4, 9.9 and $6.0 \mathrm{~kg}$ per plant, and 24.9, 38.5, 24.9 and $15.9 \mathrm{t} \mathrm{ha}^{-1}$, respectively. Based on these results, it is possible to conclude that the American and European grape cultivars evaluated present good adaptation and have high potential to be grown in the subtropical area of Parana state.
\end{abstract}

Key words: Viticulture, phenologycal stages, grape varieties, Vitis sp.

\section{INTRODUCTION}

The grape industry in Parana state, Brazil, is an important economical trade for the country. This agricultural activity stands out in two important regions: the metropolitan region of Curitiba, located in the south of the state, traditionally known for the elaboration of table wines, mainly of the cultivar Bordô; and the northern region, with vinifera table grapes, mainly 'Benitaka', 'Italia', 'Rubi' and 'Brasil'. Vinifera table grapes are planted in approximately 3.3 thousand hectares, where 105 thousand tons are harvested. In the north of the state, besides the municipality of Marialva, which contribute $42 \%$ of grape production, others such as Mandaguari, Uraí and Assaí are representative in the production of table grapes (Protas and Camargo 2011; IBGE 2012; Mello 2012).

However,with the introduction of American and hybrid grape cultivars, there has been a production diversification in recent years, aiming at the elaboration of juice and table wine. Fruit juice processors in the north of Parana are highly interested in elaborating grape juice and wine due to the increasing demand of these beverages in Brazil, although the current varieties grown are not suitable for it. Thus, as the production for the fresh market is based mainly on grapes, it is necessary to develop strategies to diversify production processes for the Parana grape industry such as wine and grape juice making.

Among grape cultivars for these purposes highlights Cabernet Sauvignon, Tannat, Isabel and Jacquez. 'Cabernet Sauvignon' and 'Tannat' started to be cultivated in Brazil in the 1980's, since they can be used to make wines with high quality (Leão et al., 2009; Sato et al., 2011). In contrast, 'Jacquez' grapes, as well as 'Isabel' grapes can be used to make juices and table wines (Sato et al., 2008a, 2008b). Considering the above aspects, the cultivation of grape cultivars for processing (juice and wine making) and market production purposes is an alternative for the grape industry development in northern Parana. However, since phenological and productive characteristics of these grapes in Parana are not known, phenological and productive characterizations of grape cultivars for production in a new area are needed. This will enable the planning of agricultural activities and the estimation of prunning and harvesting dates under each one of those conditions (Roberto et al., 2015; Santos et al., 2013).

Based on the above, the aim of this work was to characterize the phenology and physicochemical characterizations of 'Isabel', 'Jacquez', 'Cabernet Sauvignon' and 'Tannat' grapes grown in a subtropical area.

\section{MATERIAL AND METHODS}

This research was carried out in an experimental vineyard of 'Isabel' (Vitis labrusca L.) and 'Jacquez' (Vitis bourquina M.), 'Cabernet Sauvignon' and 'Tannat' (Vitis vinifera L.) grapes, located in the city of Maringá, in the north of Parana state, Brazil. The regional climate there is subtropical $(\mathrm{Cfa})$, and the average annual precipitation is around $1,600 \mathrm{~mm}$. 
The germplasm was obtained from a virus-free source (Brazilian Agricultural Research Corporation - Embrapa (Empresa Brasileira de Pesquisa Agropecuária). American grapes were planted on their own roots spaced at 4.0 x 1.0 $\mathrm{m}$, whereas European grapes were grafted on 'IAC 766 Campinas' rootstock and spaced at $4.0 \times 1.5 \mathrm{~m}$. All cultivars were supported on overhead trellis systems and pruned in a spur system (two-bud spurs). Hydrogen cyanamide (2.5\%) was sprayed on buds right after pruning for late winter dormancy breaking.

A randomized design was used as a statistical model with 20 replications for each cultivar, and each plot consisted of one vine. The experiment was initiated in July 2003, and it was evaluated for 2 consecutive cycles (2003/2004 and 2004/2005 seasons). The following grapevine characteristics were evaluated:

\section{Phenology}

For grapevine phenological evaluation, two canes were previously marked per plot. According to the classification system proposed by Baillod and Baggiolini (1993), the grapevines phenology were visually evaluated according to the duration of each of the following stages expressed in number of days: bud swell: when $50 \%$ of buds showed plumage; beginning of shoot growth: when $50 \%$ of new shoots showed small leaves; flower cluster visible: when $50 \%$ of shoots showed flower cluster; flowering: when $50 \%$ of flower clusters were in bloom (flowering); early ripening (veraison): when first traces of color appeared on $50 \%$ of berries or when $50 \%$ of berries were soft; and harvest: when $100 \%$ of berries showed intense color and reached the highest sugar rate. Finally, a diagram was elaborated for each cultivar every season, representing each stage duration in days.

\section{Thermal characterization of phenological stages}

For thermal demand characterization of all cultivars, the thermal index, also known as summation of degree-day (DD), was estimated from pruning to harvest, as well for each grapevine phenological stage. The DD calculation was performed using daily data from the Meteorological Station of Maringa State University, (Universidade Estadual de Maringá, Parana), according to the expressions proposed by Bautista and Vargas (1981): DD = (Тм - Тв) + $\left(\mathrm{TM}_{\mathrm{M}}-\mathrm{T}_{\mathrm{M}}\right)^{2}$, when $\mathrm{T}_{\mathrm{M}}>\mathrm{T}_{\mathrm{B}} ; \mathrm{DD}=\left(\mathrm{T}_{\mathrm{M}}-\mathrm{T}_{\mathrm{B}}\right)^{2} / 2\left(\mathrm{~T}_{\mathrm{M}}-\mathrm{T}_{\mathrm{M}}\right)$, when $\mathrm{T}_{\mathrm{M}}<\mathrm{T}_{\mathrm{B}}$; and $\mathrm{DD}=0$, when $\mathrm{T}_{\mathrm{B}}>\mathrm{T}_{\mathrm{M}}$; where $\mathrm{DD}=$ degree-day; $\mathrm{T}_{\mathrm{M}}=$ maximum daily temperature $\left({ }^{\circ} \mathrm{C}\right) ; \mathrm{Tm}=$ minimum daily temperature $\left({ }^{\circ} \mathrm{C}\right)$ and $\mathrm{Tb}=$ basetemperature $\left({ }^{\circ} \mathrm{C}\right)$.

The DD was then calculated for two base-temperatures $\left(10\right.$ and $\left.12{ }^{\circ} \mathrm{C}\right)$, in order to establish the lowest standard deviation (expressed in days), i.e., the temperature with the lowest standard deviation was considered as base for each phenological stage, according to the expression proposed by Arnold (1959): Sd = Sdd/xt - tb, where: $\mathrm{Sd}=$ standard deviation (days); $\mathrm{Sdd}=$ standard deviation (degree-day); $\mathrm{xt}=$ air temperature average during the period $\left({ }^{\circ} \mathrm{C}\right)$; and $\mathrm{tb}$ = base-temperature $\left({ }^{\circ} \mathrm{C}\right)$.

\section{Physicochemical characteristics of production}

The berry physicochemical characteristics of all cultivars were weekly sampled from early ripening up to 7 days after harvest. Therefore, a sample of 300 berries (10 sub-plots of 30 berries) of each cultivar was collected, and the following parameters were analyzed: mass $(\mathrm{g})$, width $(\mathrm{mm})$, total soluble solids (TSS), titratable acidity (TA) and TSS/TA. The TSS was measured using a digital refractometer with automatic temperature compensation (Model DR 301-95, A. Kruss Optronik, Germany) and results were expressed as ${ }^{\circ}$ Brix. TA was measured with a digital autotriton device (Model Tritroline Easy, Schott Gerate, Germany), setting $\mathrm{pH}=8.2$ as the end point. For TA evaluation, a standard solution of $\mathrm{NaOH} 0.1 \mathrm{~N}$ was used and the results were expressed in (\%) of tartaric acid. Regression modeling using Statistica ${ }^{\circledR}$ software version 5.0 was used to determine relationships between physicochemical properties of the grapes and the sampling date in order to predict harvest date.

At harvest, the number of clusters per plant of each plot was recorded for all grape cultivars to estimate production variables ( $\mathrm{kg}$ per plant and $\mathrm{t} \mathrm{ha} \mathrm{a}^{-1}$ ). For cluster characteristics evaluation, a sample of 5 clusters per plot was collected, and the following variables were analyzed: mass $(\mathrm{g})$ and length $(\mathrm{cm})$. Samples were analyzed at the Fruit Technology Laboratory of the State University of Londrina (Universidade Estadual de Londrina).

The berry color development of all cultivars was evaluated from early ripening to harvest using a Color Reader (Model CR 10, Minolta, US). Three measurements were made around the equatorial belt of each berry, and the color was based on CIEL*a*b* values.

The means and the standard deviations of each variable obtained individually in the evaluated seasons were considered for the discussion of the results. 


\section{RESULTS AND DISCUSSION}

\section{Phenological stages duration:}

In the 2003/2004 season (Figures 1A and 2A), the cycles of both cultivars (pruning to harvest) were similar (127 and 126 days, respectively). However, few differences were observed concerning some periods between the varieties, such as from visible flower cluster to flowering (17 and 22 days, respectively), from flowering to early ripening (65 and 55 days, respectively), and from early ripening to harvest (28 and 33 days, respectively).
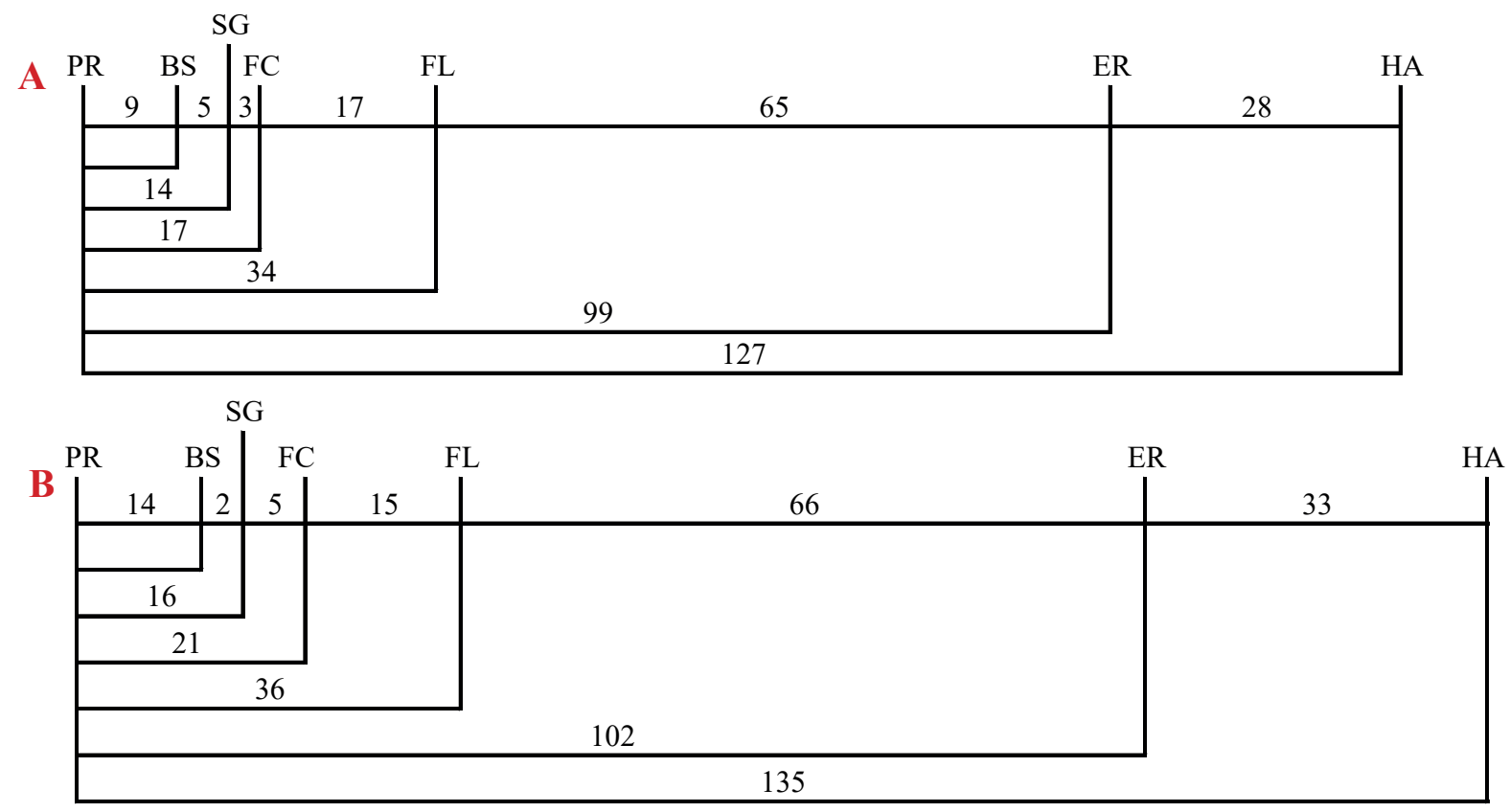

Figure 1. Duration (days) of each phenological stage of 'Isabel' grape (Vitis labrusca) cultivated in north of Parana. (A): 2003/2004; (B): 2204/2005. Pruning (PR); Bud-swell (BS); Shoot growth (SG); Flower cluster visible (FC); Flowering (FL); Early ripening (ER); Harvest (HA).
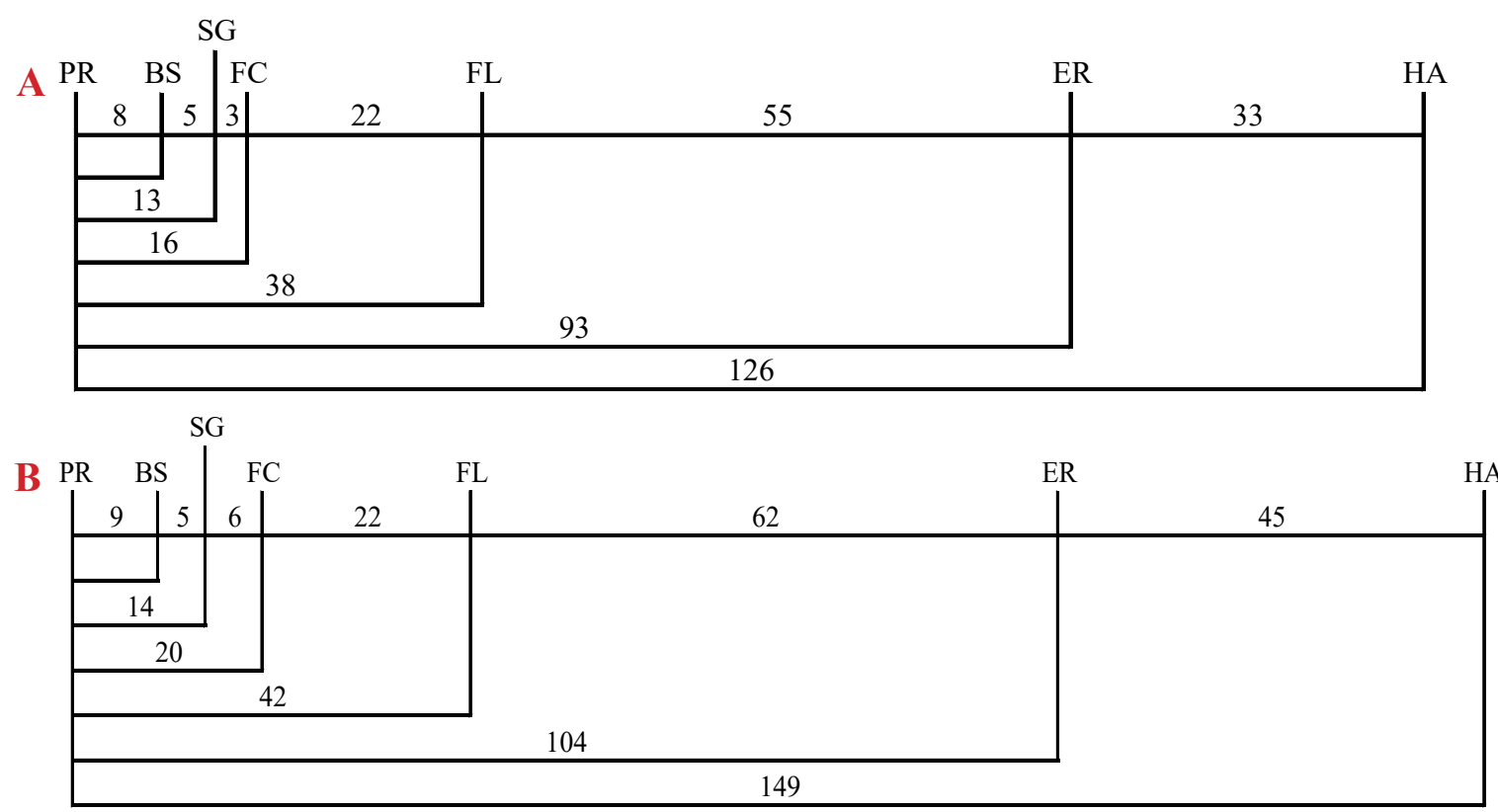

Figure 2. Duration (days) of each phenological stage of 'Jacquez' grape (Vitis bourquina) cultivated in north of Parana. (A): 2003/2004; (B): 2204/2005. Pruning (PR); Bud-swell (BS); Shoot growth (SG); Flower cluster visible (FC); Flowering (FL); Early ripening (ER); Harvest (HA).

In the 2004/2005 season (Figures 1B and 2B), the cycles of these grapes were different (135 and 149 days, respectively). The period from early ripening to harvest of both cultivars was quite different (33 and 45 days, respectively). In this period, the cycles of these grapes were longer than those of 2003/2004, probably due to 
weather conditions, i.e., rainfall during January 2005 was very high, period in which grapes were in the final stage of maturation. In addition, sunlight in this period was less intense because of the long period of rainfall, resulting in an increased period for grapes to reach maturation.

According to Sato et al. (2008a), the cultivar Jacquez, cultivated in the north of Paraná, presented cycle of 137.5 days. On the other hand, Sato et al. (2008b) related that 'Isabel' grape graft in different port grafts presented cycle of 142 at 167 days in the same region. These same grapes, 'Isabel' and 'Jacquez' cultivated in the Serra Gaúcha region, Rio Grande do Sul, presented cycle of 169 and 167, respectively (Camargo 2004). In other words, it means that the cycle of these grapes in the north of Parana is shorter than that of Serra Gaúcha, depending on the port graft being used. Roberto et al. (2004) reported that the cycle of 'Isabel' cultivated in the north of Parana was 127 days. Similar results were described by Broetto et al. (2011) and Nunes et al. (2016), who reported 'Isabel' cycle of 125 and 130 days in the city of Guarapuava, Paraná, and in São Vicente Férrer, Pernambuco, respectively. However, Lima et al. (2003) described that the 'Isabel' cycle cultivated in the Vale do São Francisco (São Francisco Valley), Pernambuco, is reduced when compared to that of the north of Parana in 2004/2005 (99 days).

These differences in cycles between regions can be explained by different weather conditions of each one, i.e., the north of Parana and the Vale do São Francisco present higher average of temperature when compared to Serra Gaucha, and as a result, the vegetative development of grapes is accelerated, reducing their cycle. However, it is important to emphasize that the weather condition in the north of Parana varies year to year, what implies that grape cycles may also change, depending on the time when dormancy breaking is applied as well.

Considering the above results, as the cycles of 'Isabel' and 'Jacquez' are similar, it is important that dormancy breaking and pruning occur at a different time to avoid concentration of some cultural practices, such as harvesting.

In the 2003/2004 season (Figures 3A and 4A), the cycle of both cultivars (pruning to harvest) was quite different (126 and 139 days for 'Cabernet Sauvignon' and 'Tannat', respectively).
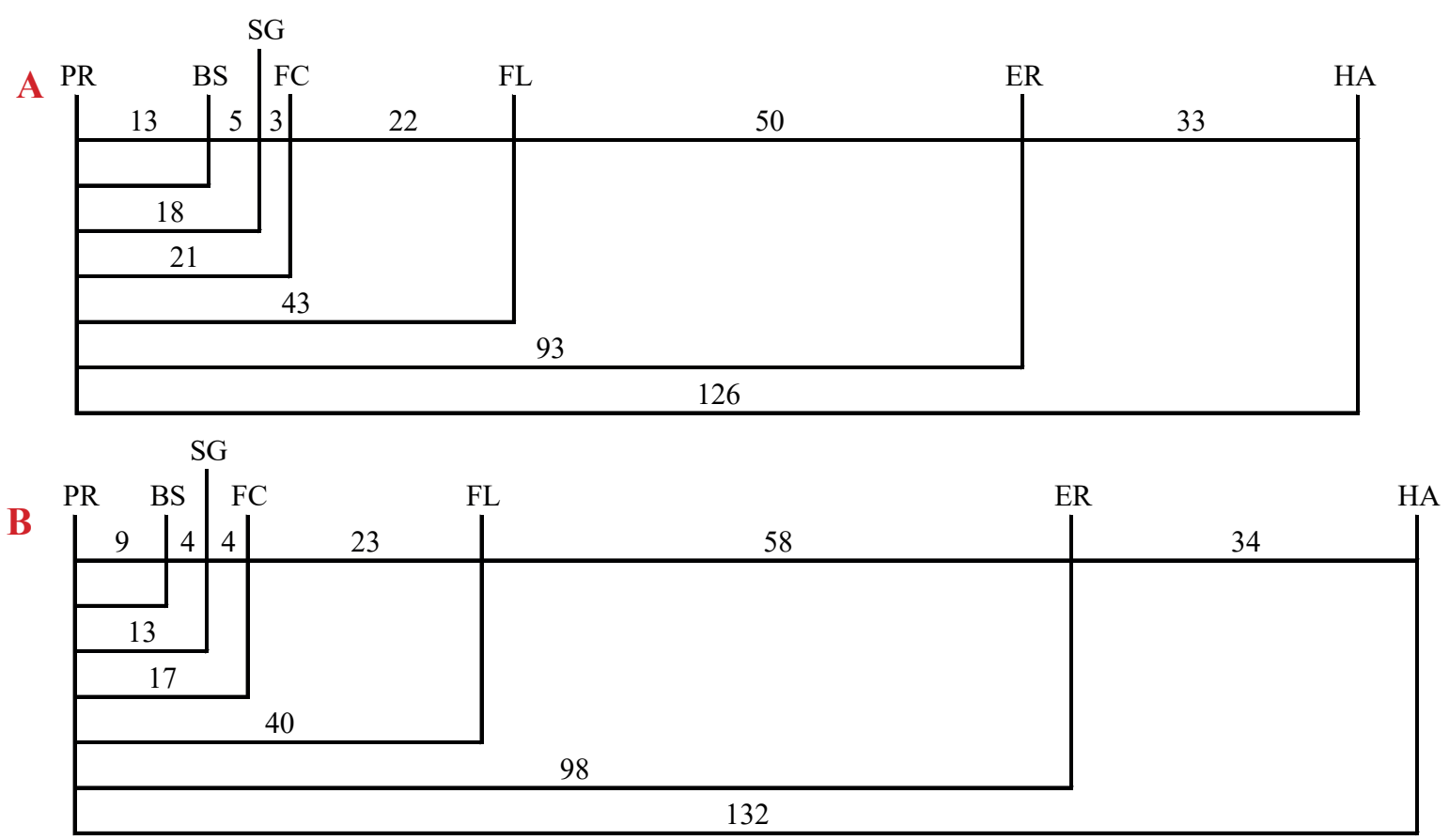

Figure 3. Duration (days) of each phenological stage of 'Cabernet Sauvignon' grape (Vitis vinifera) cultivated in north of Parana. (A): 2003/2004; (B): 2204/2005. Pruning (PR); Bud-swell (BS); Shoot growth (SG); Flower cluster visible (FC); Flowering (FL); Early ripening (ER); Harvest (HA).

The duration of phenological stages until flowering was similar between both cultivars. However, the greatest differences were observed from flowering to early ripening ( 5 days longer for 'Tannat'), and from early ripening to harvest ( 7 days longer for 'Tannat').

In the 2004/2005 season (Figures 3B and 4B), the cycle of 'Cabernet Sauvignon' was longer than the previous period (132 days), whereas for 'Tannat', the cycle was exactly the same as that observed previously (139 days). It is very important to know the difference between cycles of both cultivars grown in the north of Parana. Even though dormancy breaking and pruning are applied in the same period, fruit harvest will not occur at the same time, avoiding concentration of man-power during this critical moment. Similar results were found by Santos et al. (2007) and Sato et al. (2011) for 'Cabernet Sauvignon' and 'Tannat', that presented cycles of 130.3 at 132 and 131.3 at 139 days, respectively, in the north of Paraná.

Therefore, the phenological performance of grapes allows the definition of the time that several stages occur, 
favoring the best application of cultural practices, as well providing information to grape growers to predict harvest date.
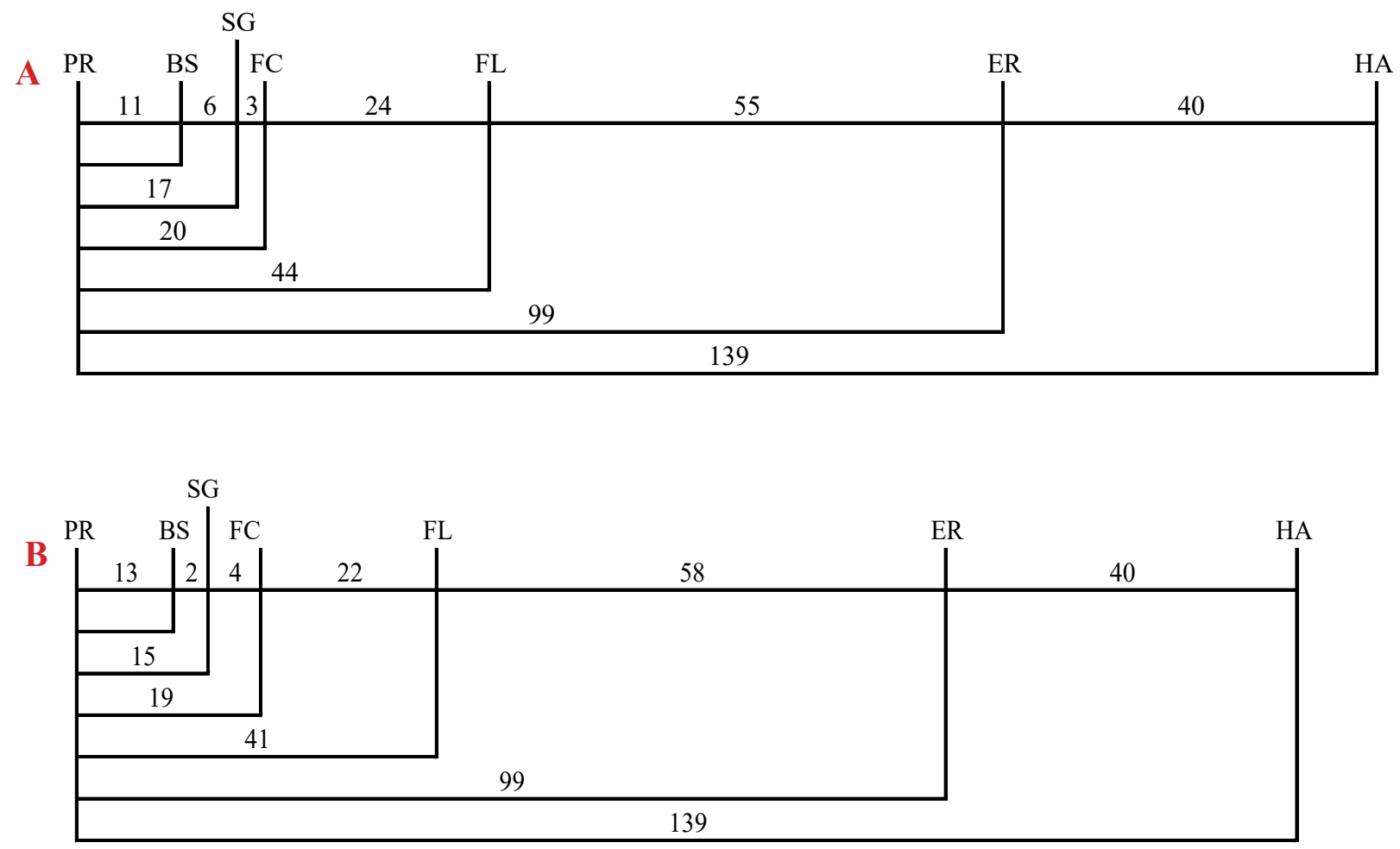

Figure 4. Duration (days) of each phenological stage of 'Tannat' grape (Vitis vinifera) cultivated in north of Parana. (A): 2003/2004; (B): 2204/2005. Pruning (PR); Bud-swell (BS); Shoot growth (SG); Flower cluster visible (FC); Flowering (FL); Early ripening (ER); Harvest (HA).

\section{Thermal demand}

The most suitable base-temperature for both cultivars observed was $10^{\circ} \mathrm{C}$, resulting in the lowest standard deviations $(\mathrm{Sd})$ in days, when compared to $12{ }^{\circ} \mathrm{C}$. Other authors reported that the most appropriate temperature to characterize their thermal demand was $10^{\circ} \mathrm{C}$ for several grape cultivars in Brazil (Nagata et al., 2000).

The thermal demand for 'Isabel' and 'Jacquez' grapes (pruning to harvest) were quite similar in the 2003/2004 season (1,238.2 and 1,287.0 DD, respectively) (Table 1). As the cycle of these cultivars were alike, the same condition was observed regarding the thermal demand in this period.

Table 1. Thermal demand, expressed in degree-days (DD), calculated for different base-temperature (10 and 12 ${ }^{\circ} \mathrm{C}$ ) and standard deviation (Sd) in days for each phenological stage for 'Isabel' (Vitis labrusca) and 'Jacquez' (Vitis bourquina) grapes in the season of 2003/2004

\begin{tabular}{|c|c|c|c|c|c|c|c|c|}
\hline \multirow{3}{*}{$\begin{array}{l}\text { Phenological } \\
\text { stage }\end{array}$} & \multicolumn{4}{|c|}{ 'Isabel' } & \multicolumn{4}{|c|}{ 'Jacquez' } \\
\hline & \multicolumn{2}{|c|}{$10^{\circ} \mathrm{C}$} & \multicolumn{2}{|c|}{$12^{\circ} \mathrm{C}$} & \multicolumn{2}{|c|}{$10^{\circ} \mathrm{C}$} & \multicolumn{2}{|c|}{$12^{\circ} \mathrm{C}$} \\
\hline & DD & Sd & DD & $\mathrm{Sd}$ & DD & Sd & DD & Sd \\
\hline PR-BS ${ }^{1}$ & 54.8 & 0.38 & 45.1 & 0.54 & 86.8 & 0.08 & 78.8 & 0.09 \\
\hline BS-SG & 56.6 & 0.10 & 51.6 & 0.11 & 35.4 & 0.12 & 30.4 & 0.16 \\
\hline SG-FC & 36.1 & 0.07 & 33.1 & 0.08 & 28.1 & 0.03 & 25.1 & 0.04 \\
\hline FC-FL & 156.9 & 0.17 & 139.9 & 0.21 & 204.9 & 0.14 & 182.9 & 0.16 \\
\hline FL-ER & 645.4 & 0.12 & 580.4 & 0.14 & 568.4 & 0.09 & 513.4 & 0.11 \\
\hline ER-HA & 288.3 & 0.06 & 260.3 & 0.07 & 364.2 & 0.05 & 330.2 & 0.06 \\
\hline PR-HA & $1,238.2$ & 0.16 & $1,110.5$ & 0.19 & $1,287.9$ & 0.12 & $1,160.9$ & 0.14 \\
\hline
\end{tabular}

${ }^{1}$ PR-BS: pruning to bud swell; BS-SG: bud swell to shoot growth; SG-FC: shoot growth to flower cluster visible; FC-FL: flower cluster visible to flowering; FL-ER: flowering to early ripening; ER-HA: early ripening to harvest; PR-HA: pruning to harvest. 
In the 2004/2005 season, the thermal demand for 'Isabel' and 'Jacquez' grapes were higher than those of the last period (1,308.1 and 1,454.5 DD, respectively) (Table 2) and, their cycles were also longer. The 'Jacquez' thermal demand in this period was higher than 'Isabel' due to its cycle, which was 14 days longer.

Table 2. Thermal demand, expressed in degree-days (DD), calculated for different base-temperature (10 and 12 ${ }^{\circ} \mathrm{C}$ ) and standard deviation (Sd) in days for each phenological stage for 'Isabel' (Vitis labrusca) and 'Jacquez' (Vitis bourquina) grapes in the season of 2004/2005.

\begin{tabular}{|c|c|c|c|c|c|c|c|c|}
\hline \multirow{3}{*}{$\begin{array}{l}\text { Phenological } \\
\text { stage }\end{array}$} & \multicolumn{4}{|c|}{ 'Isabel' } & \multicolumn{4}{|c|}{ 'Jacquez' } \\
\hline & \multicolumn{2}{|c|}{$10^{\circ} \mathrm{C}$} & \multicolumn{2}{|c|}{$12^{\circ} \mathrm{C}$} & \multicolumn{2}{|c|}{$10^{\circ} \mathrm{C}$} & \multicolumn{2}{|c|}{$12^{\circ} \mathrm{C}$} \\
\hline & $\mathrm{DD}$ & $\mathrm{Sd}$ & $\mathrm{DD}$ & $\mathrm{Sd}$ & $\mathrm{DD}$ & $\mathrm{Sd}$ & $\mathrm{DD}$ & $\mathrm{Sd}$ \\
\hline PR-BS ${ }^{1}$ & 137.5 & 0.25 & 122.5 & 0.29 & 99.6 & 0.07 & 89.6 & 0.08 \\
\hline BS-SG & 23.2 & 0.02 & 21.2 & 0.03 & 46.2 & 0.03 & 42.2 & 0.04 \\
\hline SG-FC & 59.3 & 0.11 & 54.3 & 0.13 & 76.1 & 0.02 & 70.1 & 0.02 \\
\hline FC-FL & 132.8 & 0.08 & 117.6 & 0.10 & 206.3 & 0.21 & 184.3 & 0.25 \\
\hline FL-ER & 631.7 & 0.10 & 565.7 & 0.11 & 577.2 & 0.10 & 515.0 & 0.11 \\
\hline ER-HA & 323.5 & 0.08 & 290.5 & 0.09 & 449.0 & 0.08 & 404.0 & 0.09 \\
\hline PR-HA & 1.308 .1 & 0.12 & 1.171 .9 & 0.14 & 1.454 .5 & 0.12 & 1.305 .3 & 0.14 \\
\hline
\end{tabular}

${ }^{1}$ PR-BS: pruning to bud swell; BS-SG: bud swell to shoot growth; SG-FC: shoot growth to flower cluster visible; FC-FL: flower cluster visible to flowering; FL-ER: flowering to early ripening; ER-HA: early ripening to harvest; PR-HA: pruning to harvest.

The thermal demand can also change according to the port graft used for 'Isabel' grape, according to Sato et al. (2008b). These authors observed thermal demand between 1,260.9 and 1,541.6 DD on 'Isabel' grape grafted in different port grafts in the north of Paraná. The most suitable base-temperature for both cultivars observed was $10{ }^{\circ} \mathrm{C}$, which resulted in the lowest standard deviations (Sd) in days, when compared to $12{ }^{\circ} \mathrm{C}$.

The thermal demand for 'Tannat' grape (pruning to harvest) was higher than that of 'Cabernet Sauvignon' in the season of 2003/2004 (Table 3) (1,382.9 and 1,221.2 DD, respectively), as well its cycle, according to Figures 3 and 4 previously presented.

Table 3. Thermal demand, expressed in degree-days (DD), calculated for different base-temperature $\left(10\right.$ and $\left.12{ }^{\circ} \mathrm{C}\right)$ and standard deviation (Sd) in days for each phenological stage for 'Cabernet Sauvignon' and 'Tannat' (Vitis vinifera) grapes in the season of 2003/2004.

\begin{tabular}{|c|c|c|c|c|c|c|c|c|}
\hline \multirow{3}{*}{$\begin{array}{l}\text { Phenological } \\
\text { stage }\end{array}$} & \multicolumn{4}{|c|}{ 'Cabernet Sauvignon' } & \multicolumn{4}{|c|}{ 'Tannat' } \\
\hline & \multicolumn{2}{|c|}{$10^{\circ} \mathrm{C}$} & \multicolumn{2}{|c|}{$12^{\circ} \mathrm{C}$} & \multicolumn{2}{|c|}{$10^{\circ} \mathrm{C}$} & \multicolumn{2}{|c|}{$12^{\circ} \mathrm{C}$} \\
\hline & DD & Sd & DD & $\mathrm{Sd}$ & $\mathrm{DD}$ & Sd & DD & Sd \\
\hline PR-BS1 & 95.6 & 0.36 & 81.9 & 0.48 & 92.5 & 0.26 & 80.4 & 0.35 \\
\hline BS-SG & 48.2 & 0.18 & 43.2 & 0.22 & 63.3 & 0.21 & 57.3 & 0.24 \\
\hline SG-FC & 36.4 & 0.03 & 33.4 & 0.04 & 28.4 & 0.02 & 25.4 & 0.02 \\
\hline FC-FL & 207.7 & 0.17 & 185.7 & 0.20 & 227.9 & 0.16 & 203.9 & 0.20 \\
\hline FL-ER & 498.8 & 0.13 & 448.8 & 0.15 & 549.9 & 0.11 & 494.9 & 0.13 \\
\hline ER-HA & 334.4 & 0.07 & 301.4 & 0.08 & 420.8 & 0.05 & 380.8 & 0.06 \\
\hline PR-HA & 1.221 .2 & 0.16 & 1.094 .6 & 0.19 & 1,3829 & 0.13 & 1.242 .9 & 0.16 \\
\hline
\end{tabular}

${ }^{1}$ PR-BS: pruning to bud swell; BS-SG: bud swell to shoot growth; SG-FC: shoot growth to flower cluster visible; FC-FL: flower cluster visible to flowering; FL-ER: flowering to early ripening; ER-HA: early ripening to harvest; PR-HA: pruning to harvest.

In the 2004/2005 season, the thermal demand for 'Cabernet Sauvignon' and 'Tannat' was 1,295.6 and 1,375.4 DD (Table 4), respectively, similar to the values from the previous period (2003/2004). In order to describe the thermal demand for 'Cabernet Sauvignon' and 'Tannat' in the north of Paraná, Santos et al. (2007) verified a demand of $1,295.8$ and $1,375.5 \mathrm{DD}$, respectively, for these grapes cultivars. 
Table 4. Thermal demand, expressed in degree-days (DD), calculated for different base-temperature $\left(10\right.$ and $\left.12{ }^{\circ} \mathrm{C}\right)$ and standard deviation $(\mathrm{Sd})$ in days for each phenological stage for 'Cabernet Sauvignon' and 'Tannat' (Vitis vinifera) grapes in the season of 2004/2005 period.

\begin{tabular}{|c|c|c|c|c|c|c|c|c|}
\hline \multirow{3}{*}{$\begin{array}{l}\text { Phenological } \\
\text { stage }\end{array}$} & \multicolumn{4}{|c|}{ 'Cabernet Sauvignon' } & \multicolumn{4}{|c|}{ 'Tannat' } \\
\hline & \multicolumn{2}{|c|}{$10^{\circ} \mathrm{C}$} & \multicolumn{2}{|c|}{$12^{\circ} \mathrm{C}$} & \multicolumn{2}{|c|}{$10^{\circ} \mathrm{C}$} & \multicolumn{2}{|c|}{$12^{\circ} \mathrm{C}$} \\
\hline & $\mathrm{DD}$ & Sd & DD & Sd & $\mathrm{DD}$ & Sd & DD & Sd \\
\hline PR-BS ${ }^{1}$ & 103.0 & 0.09 & 93.0 & 0.09 & 141.8 & 0.06 & 127.8 & 0.07 \\
\hline BS-SG & 47.1 & 0.04 & 43.1 & 0.04 & 23.5 & 0.02 & 21.5 & 0.02 \\
\hline SG-FC & 51.6 & 0.01 & 47.6 & 0.01 & 47.1 & 0.04 & 43.1 & 0.04 \\
\hline FC-FL & 215.0 & 0.21 & 192.0 & 0.25 & 225.1 & 0.21 & 203.1 & 0.24 \\
\hline FL-ER & 537.6 & 0.10 & 479.4 & 0.12 & 542.5 & 0.10 & 483.3 & 0.12 \\
\hline ER-HA & 341.1 & 0.08 & 307.1 & 0.10 & 395.4 & 0.08 & 355.4 & 0.10 \\
\hline PR-HA & 1.295 .6 & 0.13 & 1.162 .4 & 0.15 & 1.375 .4 & 0.12 & 1.234 .2 & 0.14 \\
\hline
\end{tabular}

${ }^{1} \mathrm{PR}-\mathrm{BS}$ : pruning to bud swell; BS-SG: bud swell to shoot growth; SG-FC: shoot growth to flower cluster visible; FC-FL: flower cluster visible to flowering; FL-ER: flowering to early ripening; ER-HA: early ripening to harvest; PR-HA: pruning to harvest

Table 5. Production characteristics of 'Isabel' (Vitis labrusca), 'Jacquez' (Vitis bourquina), 'Cabernet Sauvignon' and 'Tannat' (Vitis vinifera) grapes in the season of 2003/2004.

\begin{tabular}{|c|c|c|c|c|c|}
\hline Cultivar & $\begin{array}{l}\text { clusters } \\
\text { per tree }\end{array}$ & $\begin{array}{c}\text { production } \\
\text { per plant }^{1}(\mathbf{k g} \\
\text { per plant) }\end{array}$ & $\underset{\left(\text { ton.hat }^{-1}\right)}{\text { Yield }^{2}}$ & $\begin{array}{c}\text { cluster mass } \\
\text { (kg) }\end{array}$ & $\begin{array}{l}\text { cluster length } \\
\text { (cm) }\end{array}$ \\
\hline 'Isabel' & $30.2 \pm 9.0$ & 3.0 & 7.5 & $0.10 \pm 0.02$ & $10.7 \pm 1.3$ \\
\hline 'Jacquez' & $56.8 \pm 9.0$ & 14.2 & 35.5 & $0.25 \pm 0.05$ & $18.9 \pm 2.7$ \\
\hline $\begin{array}{l}\text { 'Cabernet } \\
\text { Sauvignon' }\end{array}$ & $26.6 \pm 6.2$ & 3.2 & 5.3 & $0.12 \pm 0.03$ & $14.5 \pm 1.2$ \\
\hline 'Tannat' & $37.9 \pm 18.0$ & 12.9 & 21.4 & $0.34 \pm 0.07$ & $14.1 \pm 1.5$ \\
\hline
\end{tabular}

${ }^{1}$ Estimation (according to the cluster mass and the number of clusters per plant).

${ }^{2}$ Estimation (according to the production per plant and the number of plants per hectare).

In the 2004/2005 season, 'Isabel' and 'Jacquez' showed 83.5 and 115.2 clusters per plant, respectively, and according to their cluster mass $(0.11$ and $0.19 \mathrm{~kg}$, respectively), the yield estimation per plant was 9.9 and $15.4 \mathrm{~kg}$, respectively, whereas the yield estimation was 24.9 for 'Isabel' and $38.5 \mathrm{t} \mathrm{ha}^{-1}$ for 'Jacquez'. At harvest, the cluster length of 'Jacquez' $(19.5 \mathrm{~cm})$ was higher than that of 'Isabel $(11.0 \mathrm{~cm}$ ) (Table 6). Regarding yield, Sato et al. (2008a) reported $37 \mathrm{t} \mathrm{ha}^{-1}$ for 'Jacquez' grape .

Table 6. Production characteristics of 'Isabel' (Vitis labrusca), 'Jacquez' (Vitis bourquina), 'Cabernet Sauvignon' and 'Tannat' (Vitis vinifera) grapes in the season of 2004/2005.

\begin{tabular}{|c|c|c|c|c|c|}
\hline Cultivar & $\begin{array}{c}\text { clusters per } \\
\text { tree }\end{array}$ & $\begin{array}{c}\text { proauction } \\
\text { per plant }^{1}(\mathrm{~kg} \\
\text { per plant) }\end{array}$ & $\begin{array}{c}\text { ylela- (ton.na }^{-} \\
\text {l) }\end{array}$ & $\begin{array}{c}\text { cluster mass } \\
(\mathbf{k g})\end{array}$ & $\begin{array}{l}\text { cluster length } \\
\text { (cm) }\end{array}$ \\
\hline 'Isabel' & $83.5 \pm 18.6$ & 9.9 & 24.9 & $0.11 \pm 0.03$ & $11.0 \pm 1.4$ \\
\hline 'Jacquez' & $115.8 \pm 20.9$ & 15.4 & 38.5 & $0.19 \pm 0.07$ & $19.5 \pm 3.4$ \\
\hline $\begin{array}{l}\text { 'Cabernet } \\
\text { Sauvignon' }\end{array}$ & $78.7 \pm 15.4$ & 9.9 & 24.9 & $0.12 \pm 0.02$ & $14.4 \pm 1.4$ \\
\hline 'Tannat' & $36.6 \pm 12.6$ & 6.0 & 15.9 & $0.16 \pm 0.05$ & $13.6 \pm 1.5$ \\
\hline
\end{tabular}

${ }^{1}$ Estimation (according to the cluster mass and the number of clusters per plant).

${ }^{2}$ Estimation (according to the production per plant and the number of plants per hectare). 
Table 7. Physicochemical characteristics of berries of 'Isabel' (Vitis labrusca), 'Jacquez' (Vitis bourquina), 'Cabernet Sauvignon' and 'Tannat' (Vitis vinifera) grapes in the season of 2003/2004.

\begin{tabular}{lccccc}
\hline Cultivar & $\begin{array}{c}\text { berry } \\
\text { width } \\
(\mathbf{m m})\end{array}$ & $\begin{array}{c}\text { berry } \\
\text { mass } \\
(\mathbf{g})\end{array}$ & $\begin{array}{c}\text { TSS } \\
\left({ }^{\circ} \text { Brix) }\right.\end{array}$ & $\begin{array}{c}\text { TA }^{2} \text { (\% of } \\
\text { tartaric acid) }\end{array}$ & TSS/TA \\
\hline 'Isabel' & $15.3 \pm 0.23$ & $3.2 \pm 0.32$ & $15.7 \pm 0.62$ & $1.2 \pm 0.04$ & $12.7 \pm 0.63$ \\
'Jacquez' & $11.0 \pm 0.51$ & $1.7 \pm 0.06$ & $17.9 \pm 0.24$ & $1.5 \pm 0.11$ & $11.9 \pm 0.99$ \\
'Cabernet Sauvignon' & $10.5 \pm 0.44$ & $1.1 \pm 0.06$ & $17.1 \pm 0.21$ & $1.1 \pm 0.13$ & $15.4 \pm 1.82$ \\
'Tannat' & $10.9 \pm 0.41$ & $1.6 \pm 0.06$ & $21.2 \pm 0.84$ & $1.0 \pm 0.08$ & $20.4 \pm 1.97$ \\
\hline
\end{tabular}

${ }^{1}$ Total soluble solids.

${ }^{2}$ Titrable acidity.

TSS concentration during harvest of 'Isabel' was lower than that of 'Jacquez' (15.7 and 17.9 oBrix, respectively). In relation to the TA concentration, similar results were also observed for these cultivars (1.2 and $1.5 \%$ of tartaric acid, respectively). However, the TSS/TA ratio of both cultivars was very similar (12.7 and 11.9, respectively).

In the 2004/2005 season, the berry mass and width of both cultivars were similar to the previous evaluation (2003/2004) (Table 8).

Table 8. Physicochemical characteristics of berries of 'Isabel' (Vitis labrusca), 'Jacquez' (Vitis bourquina), 'Cabernet Sauvignon' and 'Tannat' (Vitis vinifera) grapes in the season of 2004/2005.

\begin{tabular}{lccccc} 
Cultivar & $\begin{array}{c}\text { berry } \\
\text { width } \\
(\mathbf{m m})\end{array}$ & $\begin{array}{c}\text { berry } \\
\text { mass } \\
(\mathbf{g})\end{array}$ & $\begin{array}{c}\mathbf{T S S}^{\mathbf{1}} \\
\left({ }^{\circ} \mathbf{B r i x}\right)\end{array}$ & $\begin{array}{c}\mathbf{T A}^{2}(\% \text { of } \\
\text { tartaric acid) }\end{array}$ & TSS/TA \\
\hline 'Isabel' & $18.7 \pm 0.9$ & $3.9 \pm 0.2$ & $13.6 \pm 0.2$ & $0.7 \pm 0.1$ & $18.8 \pm 1.6$ \\
'Jacquez' & $14.5 \pm 0.8$ & $1.5 \pm 0.1$ & $15.1 \pm 0.7$ & $0.8 \pm 0.1$ & $18.0 \pm 1.1$ \\
'Cabernet Sauvignon' & $12.8 \pm 1.3$ & $1.3 \pm 0.13$ & $14.1 \pm 1.0$ & $0.8 \pm 0.10$ & $18.7 \pm 2.1$ \\
'Tannat' & $12.9 \pm 0.8$ & $1.7 \pm 0.05$ & $19.9 \pm 0.5$ & $0.7 \pm 0.05$ & $26.6 \pm 2.7$ \\
\hline
\end{tabular}

${ }^{1}$ Total soluble solids.

${ }^{2}$ Titrable acidity.

The concentration of TSS observed in 'Isabel' and 'Jacquez' during harvest were lower than that of the 2003/2004 period (13.6 and $15.1^{\circ} \mathrm{Brix}$, respectively). This can be explained by the fact that during the second year of evaluation, rainfall rate was higher during the last 2 weeks of cluster maturation, and so was sunlight appearance. For these reasons, 'Isabel' grape could not express its potential to accumulate sugars in that period. However, TA concentration of these cultivars during harvest ( 0.7 and $0.8 \%$, respectively) were lower than that of the 2003/2004 period, probably due to water supply on soil which was higher during that time, diluting organic acid on berries (Pedro Junior et al., 2014). TSS/TA ratio was similar for both cultivars during that period (18.8 and 18.0, respectively).

According to Camargo (2004), 'Isabel' and 'Jacquez' grapes grown in Serra Gaucha are harvested with TSS concentration around 18.4 and $20.8^{\circ}$ Brix, respectively, which are higher than the average observed in the north of Parana. This difference can be influenced by the cycle reduction of these cultivars in Parana, resulting in a shorter period for these grapes to accumulate sugars up to this level. Similar results were observed in the Vale do São Francisco, Pernambuco; in this region, 'Isabel' grape reaches TSS concentration of $17.2^{\circ}$ Brix during harvest (Lima et al., 2003).

In the 2003/2004 season, the number of clusters of 'Tannat' per plant was higher than that of 'Cabernet Sauvignon' (37.9 and 26.6 clusters per plant, respectively). Considering their cluster mass ( 0.34 and $0.12 \mathrm{~kg}$, respectively), a higher production per plant (12.9 and $3.2 \mathrm{~kg}$ per plant, respectively) and yield estimations (21.4 and $\left.5.3 \mathrm{t} \mathrm{ha}^{-1}\right)$ were also observed. The cluster length of both cultivars was similar (14.1 and $14.5 \mathrm{~cm}$, respectively) (Table 5).

In the 2004/2005 season, the number of clusters per plant for 'Cabernet Sauvignon' was higher than that of 'Tannat' (78.7 and 36.6 clusters per plant, respectively). Considering their cluster mass ( 0.12 and $0.16 \mathrm{~kg}$, respectively), the production estimation observed was 9.9 and $6.0 \mathrm{~kg}$ per plant; and 24.9 and $15.9 \mathrm{t} \mathrm{ha}^{-1}$, respectively (Table 6). 
The cluster length of 'Cabernet Sauvignon' was higher than that of 'Tannat' (14.4 and $13.6 \mathrm{~cm}$, respectively). On the other hand, Sato et al. (2011) observed low yield levels for 'Cabernet Sauvignon' and 'Tannat' cultivated in the north of Paraná, 8.9 and $12.1 \mathrm{tha} \mathrm{a}^{-1}$, respectively.

The yield estimation for 'Cabernet Sauvignon' in the 2004/2005 season was higher than the previous one (2003/2004), indicating that on this second year of evaluation, this cultivar was beginning to express its potential more evidently, showing better performance in relation to other regions, such as in Serra Gaucha, Rio Grande do Sul. However, the yield estimation for 'Tannat' in the season of 2004/2005 was lower than the previous one, but it was still higher than in Serra Gaucha.

For 'Cabernet Sauvignon' grapes cultivated in Serra Gaucha, cluster mass recorded was close to $0.15 \mathrm{~kg}$ (Rizzon and Miele 2002); similar to that observed in the north of Parana. Giovannini (2003) studied the yield aspects of red grapes for winemaking in Rio Grande do Sul from 1996 to 2000; this author demonstrated that 'Cabernet Sauvignon' showed yield of $11.8 \mathrm{t} \mathrm{ha}^{-1}$, whereas 'Tannat' showed $13.9 \mathrm{t} \mathrm{ha}^{-1}$ (considering old and new vineyards). In São Roque, São Paulo, for 'Cabernet Sauvignon', yield values ranged from 8.4 to $13.3 \mathrm{t} \mathrm{ha}^{-1}$, according to the pruning time (Pedro Júnior et al., 2014). In relation to berry characteristics, the berry width was similar for both cultivars in the 2003/2004 season (10.9 and $10.5 \mathrm{~mm}$, respectively), even though the berry mass of 'Tannat' (1.6 g) was higher than that of 'Cabernet Sauvigon' (1.1 g) (Table 7).

In the 2003/2004 season, TSS concentration of 'Cabernet Sauvignon' was lower than that of 'Tannat' (17.1 and $21.2^{\circ}$ Brix, respectively). For this cultivar, TSS contents were observed between 18.7 at $19.9^{\circ} \mathrm{Brix}$ due to pruning time (Pedro Júnior et al., 2014). Therefore, pruning time is another important factor to be considered to estimate the phenological behavior of grapes in different regions.

In relation to TA concentration, similar results were also obtained for these cultivars (1.1 and $1.0 \%$ of tartaric acid, respectively). TSS/TA of both grapes were different (15.4 and 20.4, respectively). TSS/TA is an index to determine grape maturation and its enological quality. However, this index must be used carefully. since an increase in TSS does not even correspond to an equal reduction in TA (Rizzon and Miele 2002).

In the 2004/2005 season, berry width was similar for 'Cabernet Sauvignon' and 'Tannat' (12.8 and $12.9 \mathrm{~mm}$, respectively). At this moment, 'Tannat' berries were slightly heavier than those of 'Cabernet Sauvignon' (1.7 and 1.3 g, respectively) (Table 8). The 'Tannat' TSS content was higher than that of 'Cabernet Sauvignon' (19.9 and 14.1 ${ }^{\circ}$ Brix, respectively). TA concentration of both cultivars were similar ( 0.8 and $0.7 \%$ of tartaric acid, respectively), but lower than the previous season (2003/2004), where the concentration was higher than $1.0 \%$ for both cultivars. It might have occurred due to the dilution of organic acids on berries. During the late harvest period, the occurrence of rainfall was high. TSS/TA for 'Tannat' was 26.6 and for 'Cabernet Sauvignon' and this relation was 18.7.

Regarding these characteristics, Sato et al. (2011), studying those cultivars in the north of Paraná, observed 14.5 ${ }^{\circ}$ Brix and $1.1 \%$ of tartaric acid for 'Cabernet Sauvignon', and $17.7^{\circ}$ Brix and $1.1 \%$ of tartaric acid for 'Tannat'.

According to Giovaninni (2003), 'Tannat' grape is harvested in Serra Gaucha with $20.1^{\circ}$ Brix, whereas Lima et al. $(2003,2004)$, described that this grape cultivated in Vale do Sao Francisco, Pernambuco, is harvested with 18.3 ${ }^{\circ}$ Brix. and under certain conditions, this concentration can reach $25.0^{\circ} \mathrm{Brix}$. The good performance of this cultivar in the north of Parana (high productivity and TSS content) during this 2-year-evaluation indicates a good adaptation to local conditions.

Regarding 'Cabernet Sauvignon' grapes in Serra Gaucha, they are harvested with $18.1^{\circ}$ Brix (Rizzon and Miele 2002), whereas Lira et al. (2003) described that this cultivar grown in Vale do Sao Francisco can reach a higher content of sugars during harvest $\left(23.5^{\circ}\right.$ Brix). Even though 'Cabernet Sauvignon' productivity in the 2004/2005 season was higher than in the previous season (2003/2004). This may be for the fact that a limit of production (kg per plant) must be respected to provide better chemical characteristics of must, such as sugar content. These questions can be answered only several years after this research is evaluated.

\section{Chemical components evolution on berries}

For both cultivars, TSS evolution was best adjusted for cubic regression $(\mathrm{P}<0.05)\left(\mathrm{R}^{2}=0.98\right.$ and 0.95 on $2003 / 2004$, Figure 5; and 0.97 and 0.92 in the season of 2004/2005, Figure 6, respectively). The early ripening period of these cultivars, considered when $50 \%$ of berries changed the color, occurred 65 and 55 days after flowering in the season of 2003/2004, and 66 and 62 days after flowering in the season of 2004/2005, respectively.

According to Blouin and Guimberteau (2000), during the herbaceous growing phase of berries, the sugar content is low. In this period, sugar is used for fruit development, as well for seed growing and maturation. When early ripening is reached, a metabolic change of sugar utilization causes a fast accumulation of this component on berries characterizing veraison. However, depending on the climate condition and cultivar, grapes cannot always be harvested when they reach the highest content of sugars. This can occur as a result of bird attack and berry cracking caused by rain, provoking fungal diseases and jeopardizing the winemaking process.

In relation to TA evolution, cubic regression was best adjusted to this characteristic for both cultivars $(\mathrm{P}<0.05)$ 
$\left(\mathrm{R}^{2}=0.93\right.$ and 0.96 in the season of 2003/2004, Figure 5; and 0.94 in the season of 2004/2005, Figure 6, respectively). TA content decrease in this phase was due mainly to the malic acid respiratory process and to the organic acid reduction in relation to the berry size increase (Mota et al., 2006).

The cubic regression also best explained the berry evolution of TSS/TA $(\mathrm{P}<0.05)(\mathrm{R} 2=0.97$ and 0.94 in 2003/2004, Figure 5; and 0.98 and 0.97 in 2004/2005, Figure 6, respectively). Until 60 days of flowering, this relation was stable, although from this date on, where the early ripening began, an accelerated increase of this relation up to the last evaluation was observed ( 7 days after harvest), caused by TSS increase and TA decrease.

For European cultivars, TSS evolution was best adjusted for cubic regression $(\mathrm{P}<0.05)(\mathrm{R} 2=0.96$ and 0.90 in 2003/2004, Figure 7; and 0.98 and 0.95 in 2004/2005, Figure 8, respectively). The early ripening period of these cultivars, considered when $50 \%$ of berries changed the color, occurred 50 and 55 days after flowering in 2003/2004, and 58 days after flowering in 2004/2005, respectively.
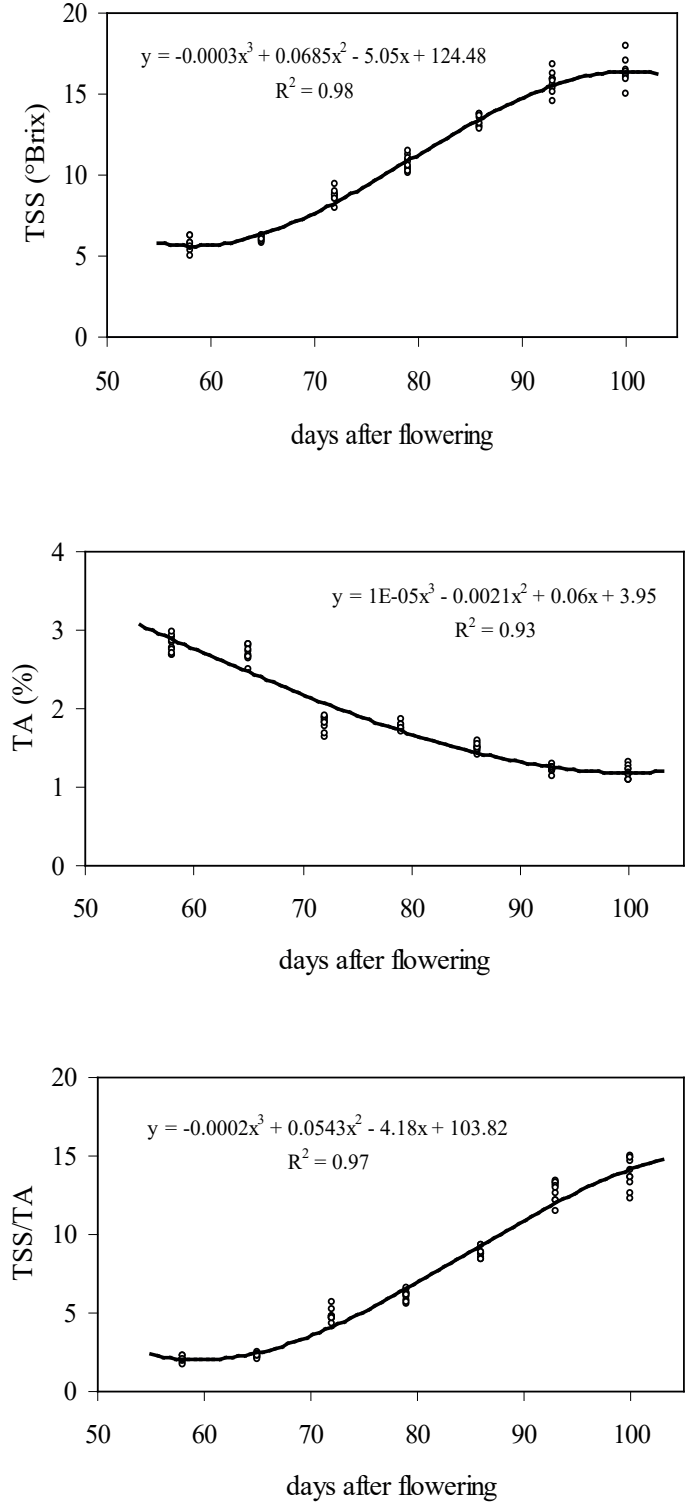
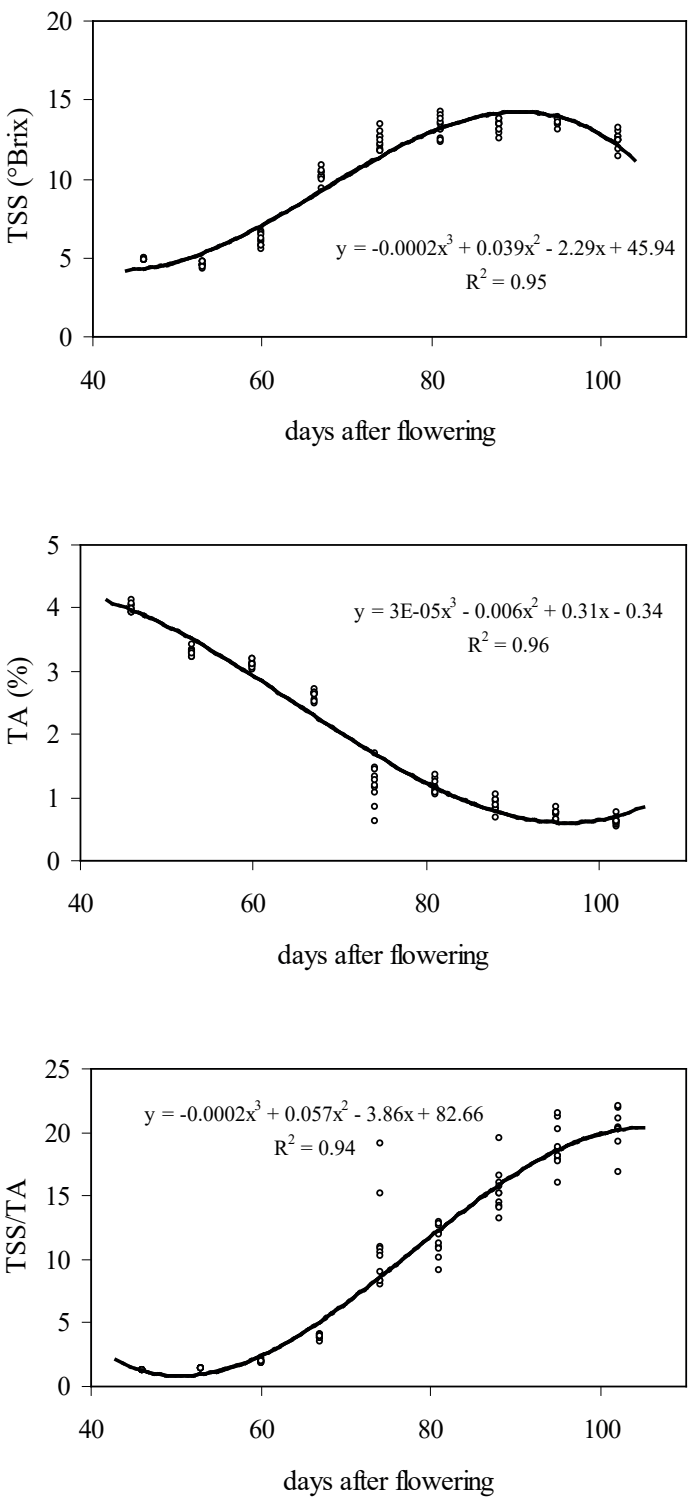

Figure 5. Evolution of total soluble solids (TSS), titrable acidity (TA) and TSS/AT of 'Isabel' grape (Vitis labrusca) in the seasons of 2003/2004 and 2004/2005. On the left: 2003/2004; on the right: 2004/2005.

TA berry evolution of 'Cabernet Sauvignon' and 'Tannat' was better explained by using the cubic regression $(\mathrm{P}<0.05)(\mathrm{R} 2=0.94$ and 0.91 in 2003/2004, Figure 7; and 0.93 and 0.94 in 2004/2005, Figure 8, respectively).

As for TSS/TA evolution, the cubic regression provided the higher determination coefficient for both cultivars $(\mathrm{P}<0.05)(\mathrm{R} 2=0.95$ and 0.98 in 2003/2004, Figure 7; and 0.96 and 0.98 in 2004/2005, Figure 8, respectively). It was possible to observe that from 50 and 60 days after flowering, this relation was stable for 'Cabernet Sauvignon' in the 2003/2004 and 2004/2005 seasons, respectively. From this date on, where the early ripening began, an accelerated increase of this relation up to the last evaluation was observed. For 'Tannat', this increase in TSS/TA relation was observed 60 days after flowering in both seasons (2003/2004 and 2004/2005). 

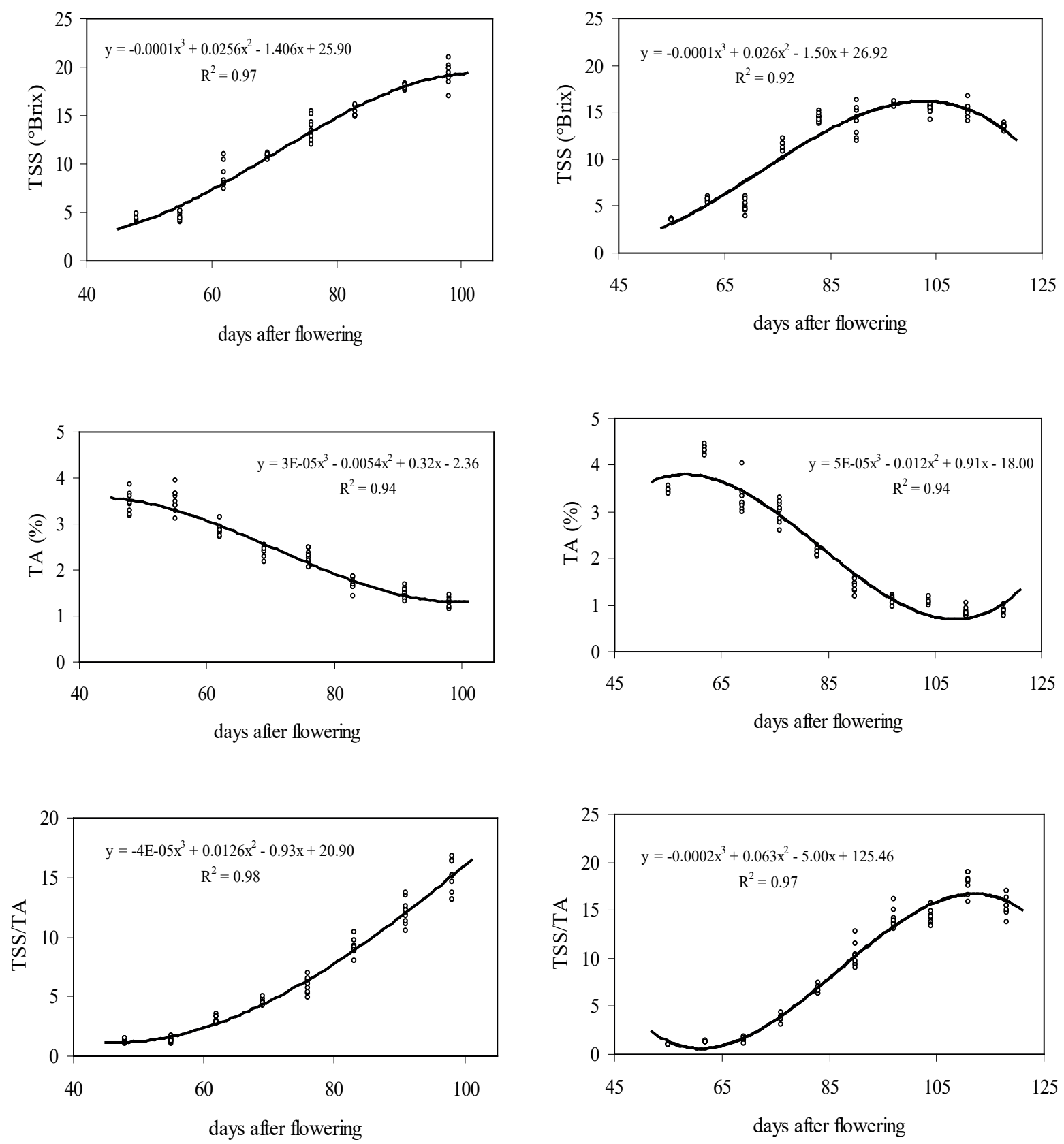

Figure 6. Evolution of total soluble solids (TSS), titrable acidity (TA) and TSS/AT of 'Jacquez' grape (Vitis bourquina) in the seasons of 2003/2004 and 2004/2005. On the left: 2003/2004; on the right: 2004/2005.

The results observed here reinforces the assumption of Gonçalves et al. (2002), who reported that quality attributes, such as TSS, TA and TSS/TA, are extremely important to monitor the ideal harvest time, providing a better control of grape material to be used for grape juice and winemaking.

\section{Berry color development}

Table 9 shows the CIEL*a*b* color attributes of berries when the clusters of American grapes were harvested. For both cultivars, $L^{*}$ was similar (23.2 and 24.0 for 'Isabel' and 'Jacquez', respectively).

As $L^{*}$ ranged from 0 to 100 (100 being the lightest) during this time, berries of 'Isabel' and 'Jacquez' tended to black. The other color attributes evaluated $\left(a^{*}\right.$ and $\left.b^{*}\right)$ were all negative, but very close to zero. As $a^{*}$ and $b^{*}$ ranged from -100 to 100 , the values observed for both cultivars associated with the respective lightness corresponded to a black color during harvest, according to the CIEL* $\mathrm{a}^{*} \mathrm{~b}^{*}$ color space.

Figure 9 represents the berry color development of 'Isabel' and 'Jacquez' over time. Considering the three attributes evaluated $\left(L^{*} a^{*} b^{*}\right)$, it was possible to verify that there is a strong change on berry color from early ripening, where the standard deviation values are higher. It occurs because at this time, berries start to change their color from green to black, i.e, $L^{*}$ decreases at this moment. However, $a^{*}$ starts to increase, whereas $b^{*}$ starts to decrease, reaching both values around zero at harvest. 

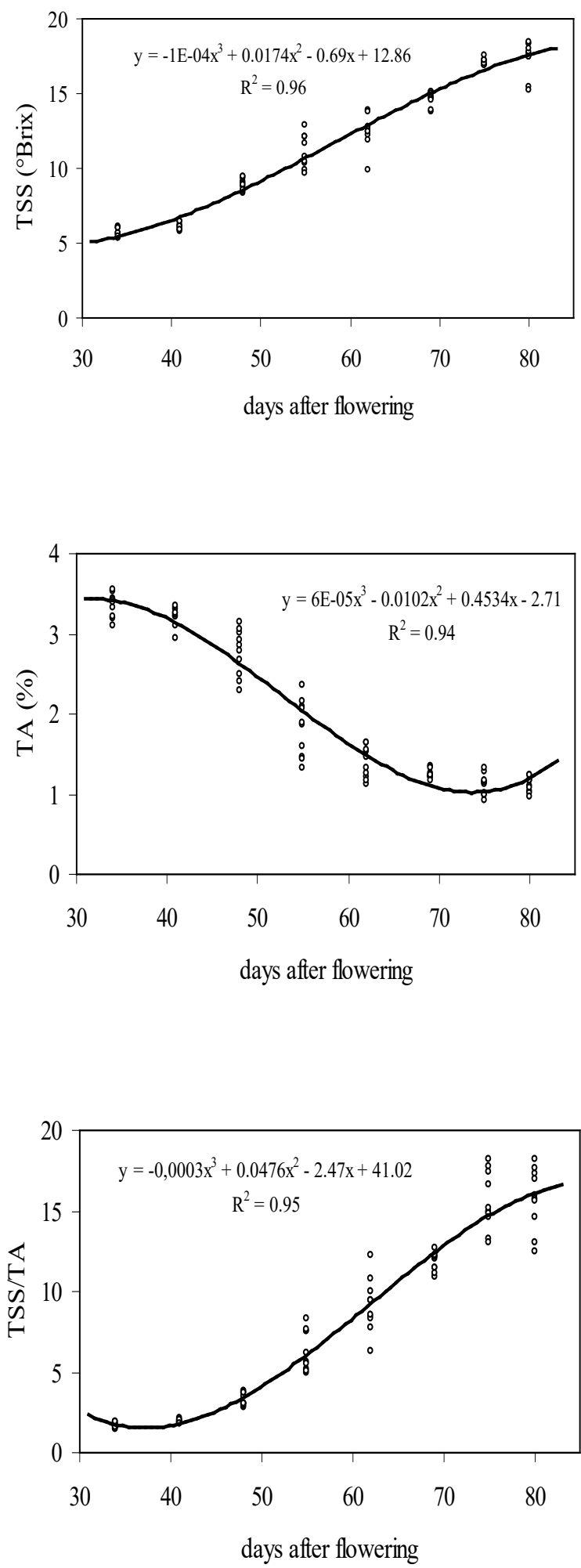
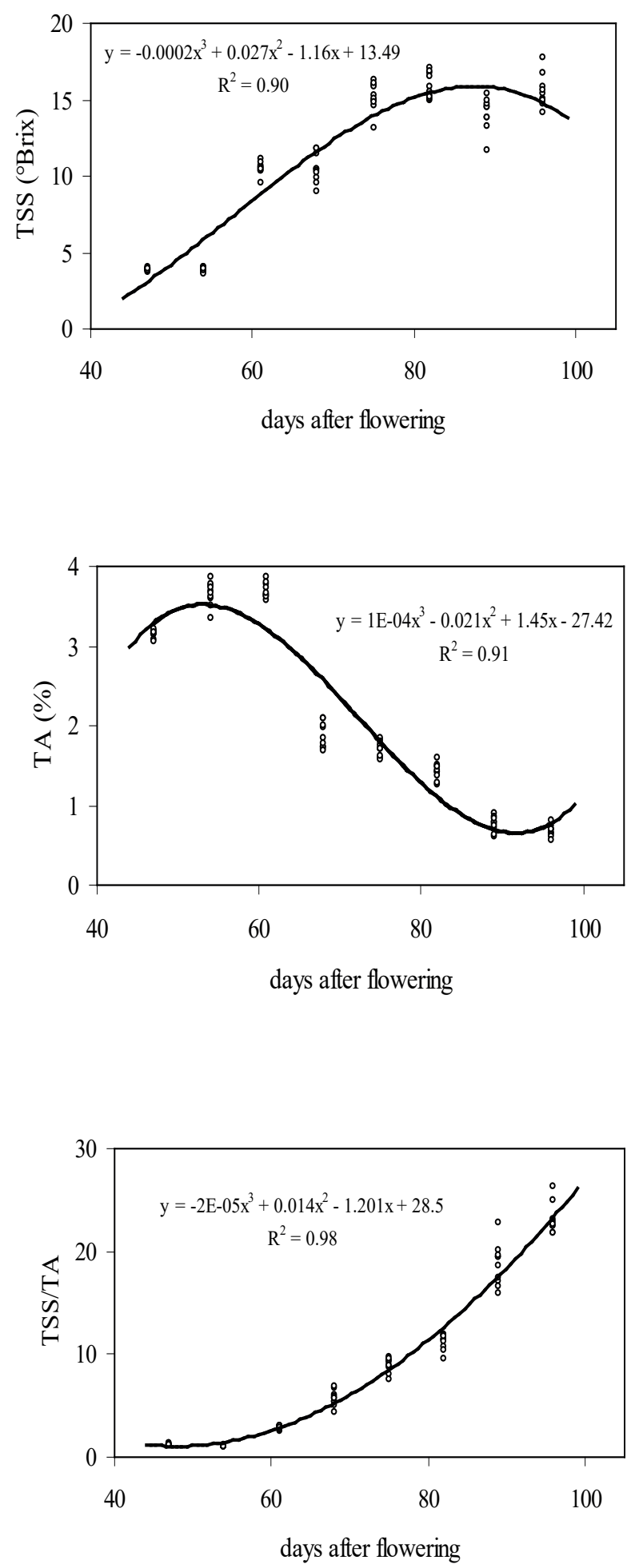

Figure 7. Evolution of total soluble solids (TSS), titrable acidity (TA) and TSS/AT of 'Cabernet Sauvignon' grape (Vitis vinifera) in the seasons of 2003/2004 and 2004/2005. On the left: 2003/2004; on the right: 2004/2005.

For 'Cabernet Sauvignon' and 'Tannat' grapes, $L^{*}$ was similar (22.8 and 22.0, respectively), providing a slightly darker color than the American grapes evaluated in this research. The $a^{*}$ and $b^{*}$ attributes also tended to zero, providing a black color of berries at harvest (Table 9).

The berry color development of both cultivars over time, considering the CIEL*a* $\mathrm{b}^{*}$ parameters, is shown in Figure 10. As discussed for American grapes, a strong change of berry color parameters was observed from early ripening. During this time, the standard deviation values were high, because the green color started to disappear. The performance of other parameters $\left(\mathrm{a}^{*}\right.$ and $\left.\mathrm{b}^{*}\right)$ was similar to the observed for American grapes. 
The results in this research are similar to those reported by Granado et al. (2001) and Zurbano et al. (2001), who studied the berry color of 'Garnacha' and 'Tempranillo' red grapes during maturation in La Rioja, Spain. The authors described that at the end of maturation, as $L^{*}$ was low and $a^{*}$ and $b^{*}$ values were very close to zero, the color of grapes tended to black, being impossible to distinguish them through human's eye.

The color analysis showed to be a useful tool to evaluate the berry color of grape cultivars in this research. As color is related to the presence of anthocyanins on berry skin, the $L^{*} a^{*} b^{*}$ values observed for all cultivars at harvest, as well the evolution of these attributes over time, confirmed that these grapes reach a color pattern compatible for processing purposes.
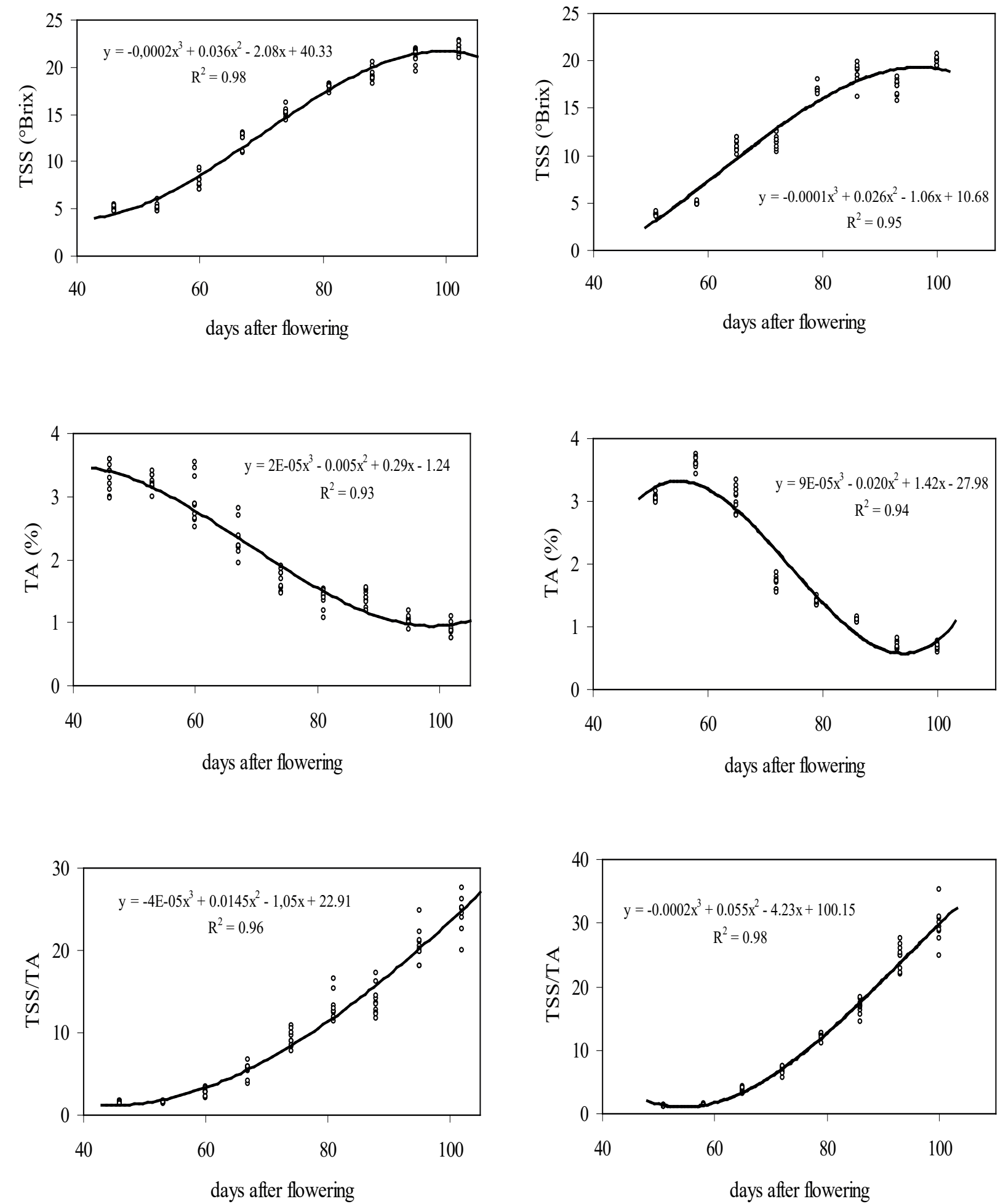

Figure 8. Evolution of total soluble solids (TSS), titrable acidity (TA) and TSS/AT of 'Tannat' grape (Vitis vinifera) in the season of 2003/2004 and 2004/2005. On the left: 2003/2004; on the right: 2004/2005. 
Table 9. Berry color of 'Isabel' (Vitis labrusca), 'Jacquez' (Vitis bourquina), 'Cabernet Sauvignon' and 'Tannat' grapes (Vitis vinifera) based on CIEL*a*b* during harvest on 2004/2005.

\begin{tabular}{lccc}
\hline Cultivar & $\boldsymbol{L}^{*}$ & $\boldsymbol{a}^{*}$ & $\boldsymbol{b}^{*}$ \\
\hline 'Isabel' & $23.2 \pm 2.0$ & $-0.3 \pm 0.9$ & $-0.6 \pm 1.5$ \\
'Jacquez' & $24.0 \pm 2.7$ & $-2.6 \pm 1.2$ & $-1.4 \pm 1.9$ \\
'Cabernet Sauvignon' & $22.8 \pm 2.1$ & $-0.9 \pm 0.7$ & $0.6 \pm 3.0$ \\
'Tannat' & $22.0 \pm 2.6$ & $-0.4 \pm 2.7$ & $-0.01 \pm 3.2$ \\
\hline
\end{tabular}

$L^{*}$ : lightness.

$a^{*}$ : position between red and green (the smallest $a^{*}$ yields green).

$b^{*}$ : position between yellow and blue (the smallest $b^{*}$ yields blue).
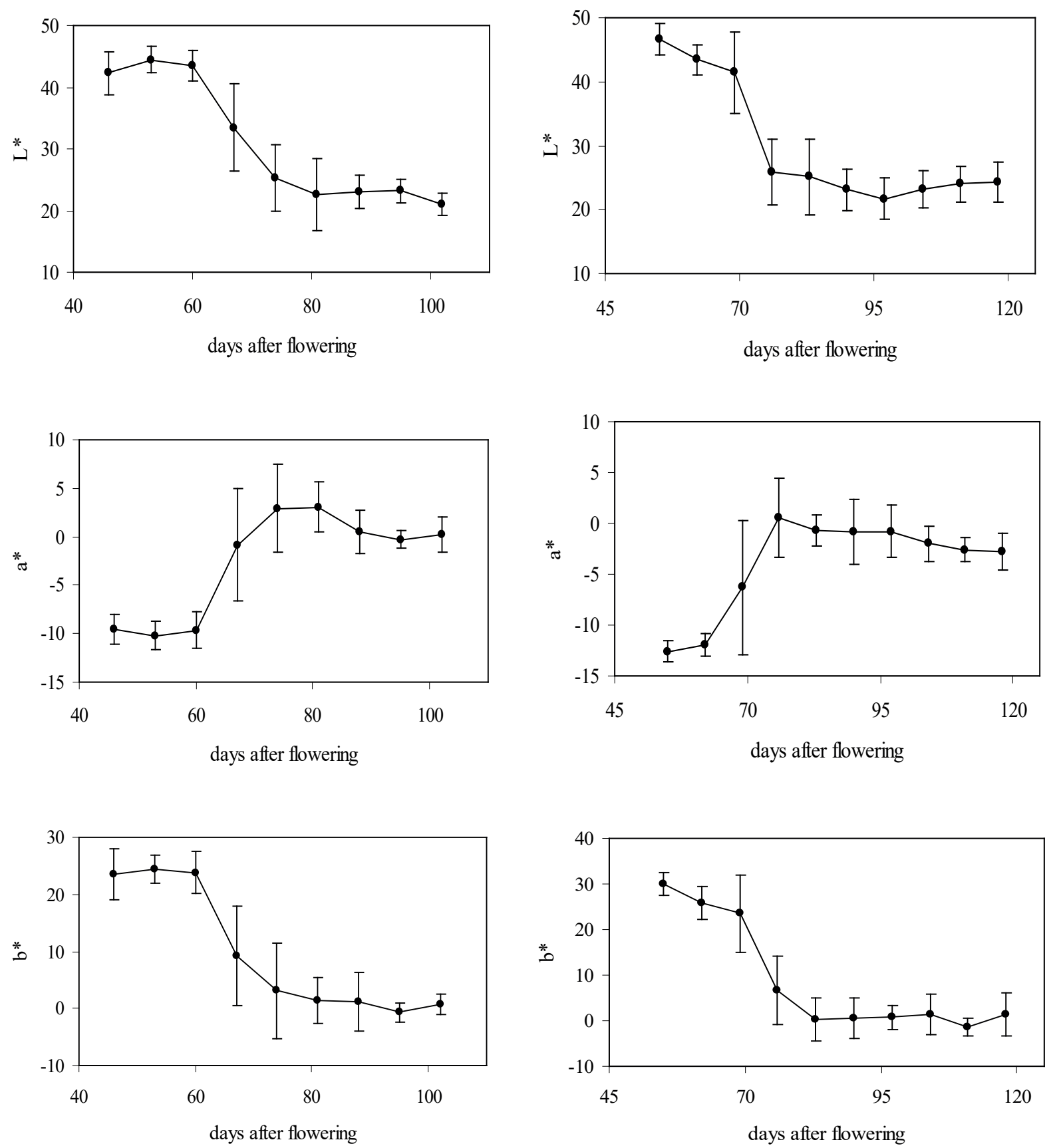

Figure 9. Berry color (CIEL*a*b*) development of 'Isabel' (on the left) and 'Jacquez' (on the right) in the season of 2004/2005. ( $L^{*}$ : lightness; $a^{*}$ : position between red and green - the smallest $a^{*}$ yields green; $b^{*}$ : position between yellow and blue - the smallest $b^{*}$ yields blue). Bars represent standard deviation. 

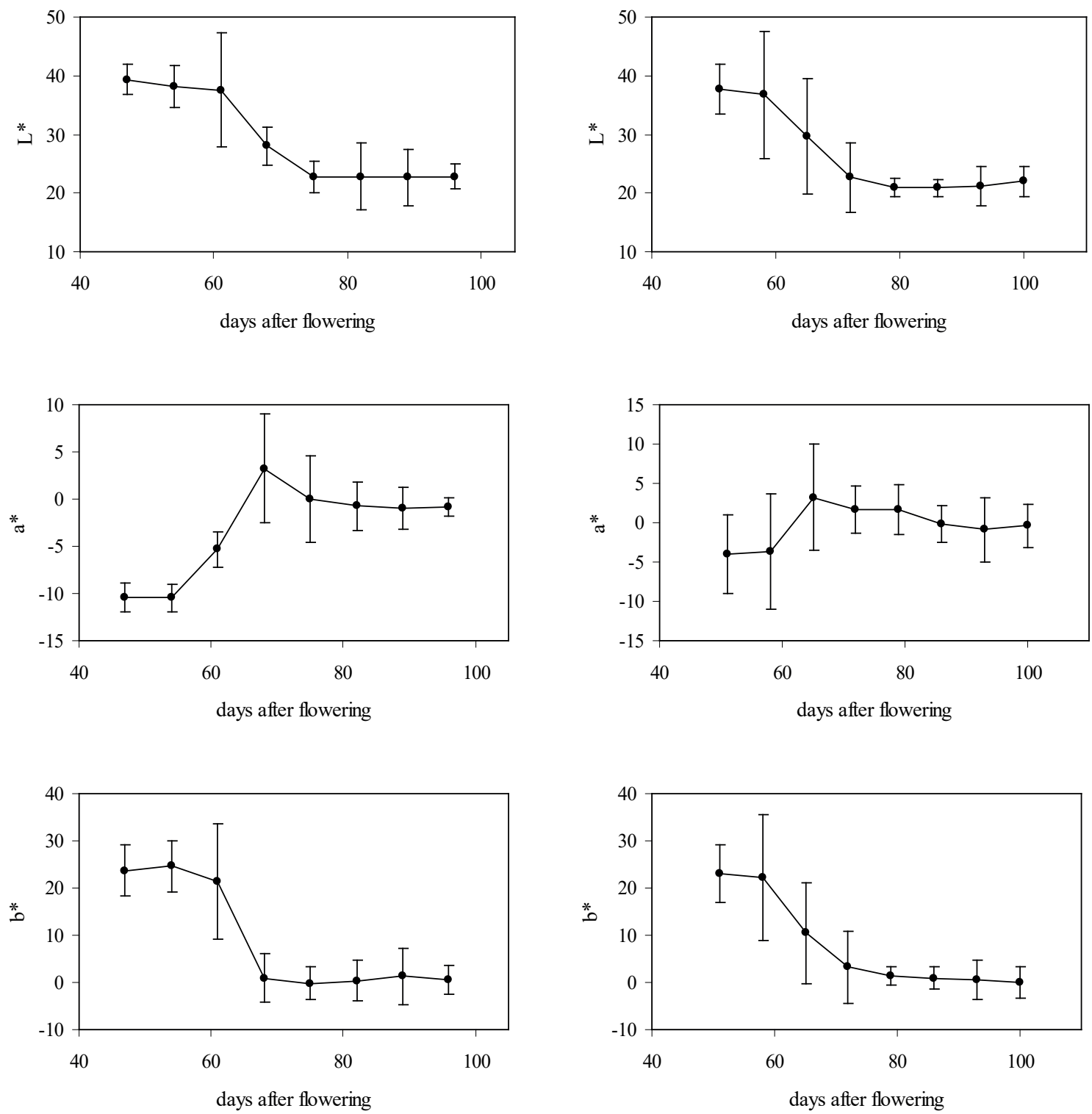

Figure 10. Berry color (CIEL*a*b*) development of 'Cabernet Sauvignon' (on the left) and 'Tannat' (on the right) in the season of 2004/2005. ( $L^{*}$ : lightness; $a^{*}$ : position between red and green - the smallest $a^{*}$ yields green; $b^{*}$ : position between yellow and blue - the smallest $b^{*}$ yields blue). Bars represent standard deviation.

\section{CONCLUSIONS}

Considering the main evaluated characteristics of 'Isabel', 'Jacquez', 'Cabernet Sauvignon' and 'Tannat' grapes, such as duration of the main phenological stages, physicochemical properties and yield, these cultivars present good adaptation and high potential to be grown in the subtropical area of Parana state.

\section{ACKNOWLOGMENTS}

The authors would like to express their sincere gratitude to IFS - International Foundation for Science, Sweden, for the financial support.

\section{REFERENCES}

Arnold CY (1959) The determination and significance of the base temperature in a linear heat unit system. Proceedings America Society for Hortculture Science 74: 430-445. 
Baillod M and Baggiolini M (1993) Les stades repères de la vigne. Revue Suise Viticulture, Arboriculture, Horticulture 25: 7-9.

Bautista D and Vargas G (1981) Estudio del ciclo y determinación de los requerimientos heliotermicos de algunas variedades de vid en condiciones tropicales. Agronomia Tropical 31: 11-23.

Blouin J and Guimberteau G (2000) Maturation et maturité des raisins. Féret, Bordeaux, 151p.

Broetto D, Baumann Junior O, Sato AJ and Botelho RV (2011) Desenvolvimento e ocorrência de pérola-da-terra em videiras rústicas e finas enxertadas sobre os porta-enxertos 'VR 043-43' e 'Paulsen 1103'. Revista Brasileira de Fruticultura 33(spe1): 404-410.

Camargo UA (2004) Uvas americanas e híbridas para processamento em clima temperado: porta-enxertos e cultivares. http://www.cnpuv.embrapa.br/publica/sprod/uva/cultivar.htm. Accessed 11 November 2016.

Giovannini E (2003) Avaliação da adaptabilidade de cvs. para vinho fino na Campanha e na Serra Gaúcha através do teor de açúcar e da produtividade. In: Anais do X Congresso Brasileiro de Viticultura e Enologia. Embrapa Uva e Vinho, Bento Gonçalves, p.184.

Gonçalves CAA, Lima LCO, Chalfun NNJ, Regina MA, Alvarenga AA and Souza MT (2002) Fenologia e qualidade do mosto de videiras 'Folha de Figo' sobre diferentes porta-enxertos, em Caldas, sul de Minas Gerais. Ciência Agrotécnica 26(6): 1178-1184.

Granado JFE, Zurbano FA, Abril MA and Suberviola AIN (2001) Estudio del color de uvas y mostos de la variedade Garnacha durante la maduración. Años 1998 y 1999. In: Anais da VI Jornadas Científicas, Grupos De Investigación Enológica. Universidad Politécnica de Valencia, Valencia, p.36-37.

IBGE - Instituto Brasileiro de Geografia e Estatística (2012) Produção Agrícola Municipal. Http://www.sidra.ibge. gov.br. Accessed on 18 august 2016.

Leão PCS, Soares JM and Rodrigues BL (2009) Principais cultivares. In: Soares JM and Leão PCS. A vitivinicultura no semiárido brasileiro. Embrapa Informação Tecnológica, Brasília, pp.151-214.

Lima MA, Leão PCS, Ribeiro APL and Trindade DCG (2003) Maturação de cultivares de uva nas condições do Submédio São Francisco. In: Anais do X Congresso Brasileiro de Viticultura e Enologia. Embrapa Uva e Vinho, Bento Gonçalves, p.196.

Lima MA, Leão PCS, Silva AL, Azevedo SSN and Santos OS (2004) Maturação de uvas para vinho no Vale do São Francisco. In: Anais do XVIII Congresso Brasileiro de Fruticultura. Sociedade Brasileira de Fruticultura, Florianópolis.

Lira MMP Arnauld AA, Guerra CC, Lima MVDO and Xavier PR (2003) Características físico-químicas da uva das cultivares Cabernet Sauvignon e Viognier cultivadas no Vale do Submédio do São Francisco. In: Anais do X Congresso Brasileiro de Viticultura e Enologia. Embrapa Uva e Vinho, Bento Gonçalves, p.194.

Mello LMR (2012) Vitivinicultura brasileira: Panorama 2011. Comunicado técnico, 125.Embrapa,Bento Gonçalves, $4 \mathrm{p}$.

Mota RV, Regina MA, Amorim DA and Fávero AC (2006) Fatores que afetam a maturação e a qualidade da uva para vinificação. Informe Agropecuário 27: 56-64.

Nagata RK, Scarpare Filho JA, Kluge RA and Nova NAV (2000) Temperatura-base e soma térmica (graus-dia) para videiras 'Brasil' e 'Benitaka'. Revista Brasileira de Fruticultura 22(3): 329-333.

Nunes NAS, Leite AV and Castro CC (2016) Phenology, reproductive biology and growing degree days of the grapevine 'Isabel' (Vitis labrusca, Vitaceae) cultivated in northeastern Brazil. Brazilian Journal of Biology 'In Press'. Pedro Júnior MJ, Hernandes JL, Blain GC and Bardin-Camparotto L (2014) Produtividade, fenologia e maturação da 'Cabernet Sauvignon' para diferentes épocas de poda. Ciência e Técnica Vitivinicola 29: 9-15. 
Protas JFS and Camargo A (2011) Vitivinicultura brasileira: panorama setorial de 2010. Ibravin. Embrapa Uva e Vinho, Bento Gonçalves, 110 p.

Regina MA, Pereira GE, Lima LCO and Rodrigues DJ (2003) Caracterização agronômica de cinco variedades de videira destinadas à elaboração de sucos de uvas na região de Caldas-MG. In: Anais do X Congresso Brasileiro de Viticultura e Enologia. Embrapa Uva e Vinho, Bento Gonçalves, p.197.

Rizzon LA and Miele A (2002) Avaliação da cv. Cabernet Sauvignon para elaboração de vinho tinho. Ciência e Tecnologia de Alimentos 22(2): 192-198.

Roberto SR, Sato AJ, Brenner EA, Santos CE and Genta W (2004) Fenologia e soma térmica (graus-dia) para a videira 'Isabel' (Vitis labrusca) cultivada no Noroeste do Paraná. Semina: Ciências Agrárias 25(4): 273-280.

Roberto SR, Mashima CH and Colombo RC (2015) Phenological characterization and quality of fine 'Black Star' table grape. Agronomy Science and Biotechnology 1(2): 77-82.

Santos CE, Roberto SR, Sato AJ and Jubileu BS (2007) Caracterização da fenologia e da demanda térmica das videiras 'Cabernet Sauvignon' e 'Tannat' para a região norte do Paraná. Acta Scientiarum Agronomy 29(3):361-366.

Santos AEO, Silva EO, Oster AH, Mistura C and Santos MO (2013) Resposta fenológica e exigência térmica de uvas apirenas cultivadas no Submédio do São Francisco. Agrária - Revista Brasileira de Ciências Agrárias 8(3): 364369.

Sato AJ, Brenner EA, Santos CE and Roberto SR (2008a) Comportamento fenológico e produtivo da videira 'Jacquez' (Vitis bourquina) no norte do Paraná. Acta Scientiarum Agronomy 30: 231-237.

Sato AJ, Jubileu BS, Santos CE, Bertolucci R, Santos R, Carielo M, Guiraud MC, Fonseca ICB and Roberto SR (2008b) Fenologia e demanda térmica das videiras 'Isabel' e 'Rubea' sobre diferentes porta-enxertos na Região Norte do Paraná. Semina: Ciências Agrárias 29: 283-292.

Sato AJ, Jubileu BS, Assis AM and Roberto SR (2011) Fenologia, produção e composição do mosto da 'Cabernet Sauvignon'e 'Tannat' em clima subtropical. Revista Brasileira de Fruticultura 33(2): 491-499.

Zurbano FA, Abril MA, Granado JFE and Suberviola AIN (2001) Estudio del color de uvas y mostos de la variedade Tempranillo durante la maduración. Años 1998 y 1999. In: Anais da VI Jornadas Científicas, Grupos de Investigación Enológica. Universidad Politécnica de Valencia, Valencia, p.34-35.

Received:June 20, 2017.

Accepted: August 10, 2017.

Published: December 15, 2017. 